\title{
THE PLASMA NON-PROTEIN NITROGEN DISTRIBUTION AND ITS CORRELATION WITH THE EFFICACY OF FLUID REPLACEMENT THERAPY FOLLOWING THERMAL INJURY ${ }^{1}$
}

\author{
By OTTO ROSENTHAL, AND M. D. McCARTHY \\ (From the Harrison Department of Surgical Research, Schools of Medicine, \\ University of Pennsylvania, Philadelphia)
}

(Received for publication September 6, 1946)

It has been previously pointed out by us (1) that the rise of the undetermined and the amino nitrogen in the plasma of scalded rats is directly related to the severity of the burn. In the present paper it will be shown that the extent to which the increases in these two nitrogen fractions are reduced by therapeutic measures provides an index of efficacy of the fluid and salt treatment. The therapeutic agencies under comparison were physiological saline, gelatin, albumin, and plasma, which were administered intravenously to the scalded rats at varying intervals of time and in varying quantities. In addition to the effect of these substances upon the azotemia, their influence upon the urinary excretion of water and nitrogen was investigated.

\section{EXPERIMENTAL METHODS}

The standardized back-burn procedure, the collection of blood, and the determination of non-protein nitrogen, urea nitrogen, and amino nitrogen in tungstic acid filtrates of the plasma have been previously described (1, 2 ). The difference (non-protein nitrogen - [urea nitrogen + amino nitrogen]) will be referred to as the undetermined plasma nitrogen.

Plasma protein levels were calculated by multiplying the difference (total plasma nitrogen - non-protein nitrogen) by the factor 6.25 . The estimation of the gelatin content of plasma following the infusion of this plasma substitute was based upon the fact that 3 per cent trichloracetic acid precipitates only the plasma proteins while tungstic acid removes both plasma protein and gelatin. The gelatin solution used for infusion contained $1.0 \mathrm{gram}$ of precipitable nitrogen per $\mathbf{5 . 5}$ grams of gelatin. Hence the term (non-protein nitrogen of the trichloracetic acid filtrate - non-protein nitrogen of the tungstic acid filtrate) $\times 5.5$ provides an estimate of the gelatin level of plasma.

Urine was collected under "Klarol" 2 in separatory

1 Part of the results have been presented at a Meeting of the Physiological Society of Philadelphia on October 15, 1946 (Am. J. Med. Sci., 1946, 212, 755).

2 A very light mineral oil manufactured by Sonneborn and Son, N. J. funnels ${ }^{3}$ which were placed under metabolism cages. The funnels were drained for measurement and analysis of the urine at intervals of 12,21 , or 24 hours as required. Analyses of total nitrogen, non-protein nitrogen,4 urea nitrogen, and ammonia nitrogen were carried out with the method of Sobel, Mayer, and Gottlieb (3). The difference (non-protein nitrogen - [urea + ammonia nitrogen]) will be referred to as the undetermined urinary nitrogen.

During the first 24 hours following scalding the rats received no food. Thereafter they were fed in separate cages for periods of 2 hours in the morning and 1 hour in the afternoon, a procedure recommended by Croft and Peters (4). Urine voided during the periods of feeding was absorbed in filter paper. The paper was then extracted with $\mathrm{N} / 50$ sulfuric acid and an aliquot of the extract analyzed for urea + ammonia nitrogen. The nitrogen content and the volume of the 3-hour specimens were computed on the assumption that the nitrogen partition and the nitrogen concentration were identical with those of the corresponding 21-hour specimens of known volume and composition.

The urine of rats contains normally a small amount of protein (5). Only during the first day or 2 following the burn, however, were the total nitrogen values of the samples distinctly above the non-protein nitrogen values. Hence, for collection periods other than the first 48 hours following burn, non-protein nitrogen analyses were often omitted and only the total nitrogen determined in addition to urea and ammonia nitrogen.

The following agents were used in the transfusion experiments: (1) 0.85 per cent sodium chloride solution referred to thereafter as saline; (2) 4 per cent gelatin solution (Knox P-20). In addition to $726 \mathrm{mgm}$. of nitrogen precipitable with tungstic acid, $100 \mathrm{ml}$. of the gelatin solution contained $12.5 \mathrm{mgm}$. of undetermined nitrogen, $2.5 \mathrm{mgm}$. of amino nitrogen, $1.25 \mathrm{mgm}$. of ammonia nitrogen and $0.63 \mathrm{mgm}$. of urea nitrogen, the latter prob-

\footnotetext{
8 In glass funnels filled with a non-polar medium, such as mineral oil, water droplets stick rather tightly to the glass walls and are only incompletely removable mechanically. Perfect drainage was obtained when, on the suggestion of Dr. K. C. Blodgett of the General Electric Research Laboratory, the funnels were coated with a water repelling surface film. We are grateful to the Chemical Department of the General Electric Company, Schenectady, N. Y., for a gift of DRI-FILM No. 9987.

4 The urines were deproteinized with tungstic acid.
} 
ably derived from arginin; (3) 5 per cent human albumin solution containing 1.06 per cent of sodium chloride. This infusion fluid was prepared by adding 4 parts of saline to 1 part of a 25 per cent solution of normal human serum albumin (Lederle) containing 1.8 per cent of sodium chloride; (4) plasma from citrated or heparinized rat blood. The curative effectiveness of both types of rat plasma was identical. Infusion intervals and volumes are given in the figures and tables.

The standard for computing mortality rates was 10 days' survival. The rates referred to in the following sections were obtained in separate experimental series which will be discussed elsewhere (6).

\section{EXPERIMENTAL RESULTS}

\section{Effect of fluid replacement on azotemia}

Figure 1 illustrates the effect of the intravenous infusion of saline on the non-protein nitrogen levels in the plasma of scalded rats. It is seen that a single infusion, when administered 2 hours after the burn in an amount corresponding to 2 per cent of the body weight, failed to retard the increase of the plasma nitrogen. Repetition of the infusion at 5 hours after the burn prevented a further rise of the undetermined and the amino nitrogen fractions and reduced the mortality rate of the group to 50 per cent. In the survivors examined 24 hours after the burn, these 2 nitrogen fractions had returned to approximately normal level. When the saline infusion was increased to 10 per cent of the body weight of the animal, approximately normal levels were found as early as 12 hours after the burn and all animals survived. It should be noted that the urea nitrogen levels fell much more slowly. Normal urea levels were not obtained until 48 hours after the scalding. This slow reduction in the presence of effective therapy is in keeping with our previous conclusion (1) that there is no definite correlation between the accumulation of urea in the plasma and the severity of the scald or the prognosis.

For comparing the therapeutic action of plasma and colloidal plasma substitutes with that of saline, an arrangement was needed where saline therapy was only of limited value. For this purpose the 30 per cent surface-35-second scald was chosen, which renders the animals less responsive to saline therapy than does the 45 per cent surface-15-second scald. The volumes of the different agents administered corresponded to 4 per cent of the body weights of the animals, the maximum amount that could be given in the case of colloidal solution without leading to undesirable large increases of the circulating blood volume. Under these circumstances the survival rate following saline therapy was 29 per cent.

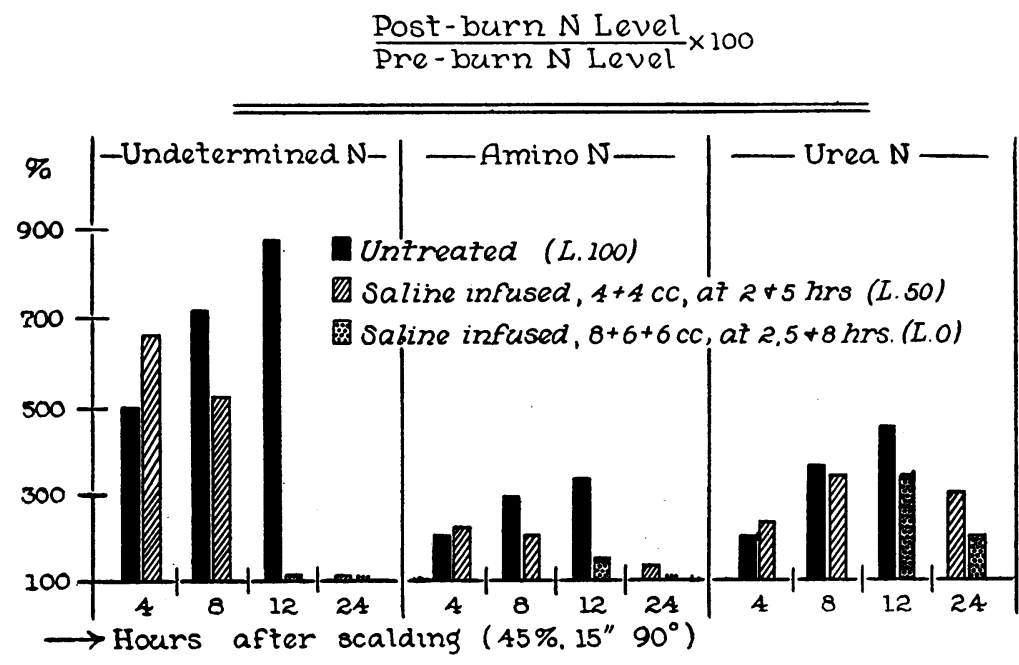

Fig. 1. Effrect of the Infusion of Varying Volumes of Saline on the Non-Protein Nitrogen Levels of Scalded Rats

Forty-five per cent body surface, $90^{\circ}$ C., 15 seconds' scald. Pooled blood from 2 to 4 rats was used for the individual determinations. The nitrogen levels are represented as percentages of the average levels in normal rats. The letter $L$ denotes the average percentile lethality in the animal series. 

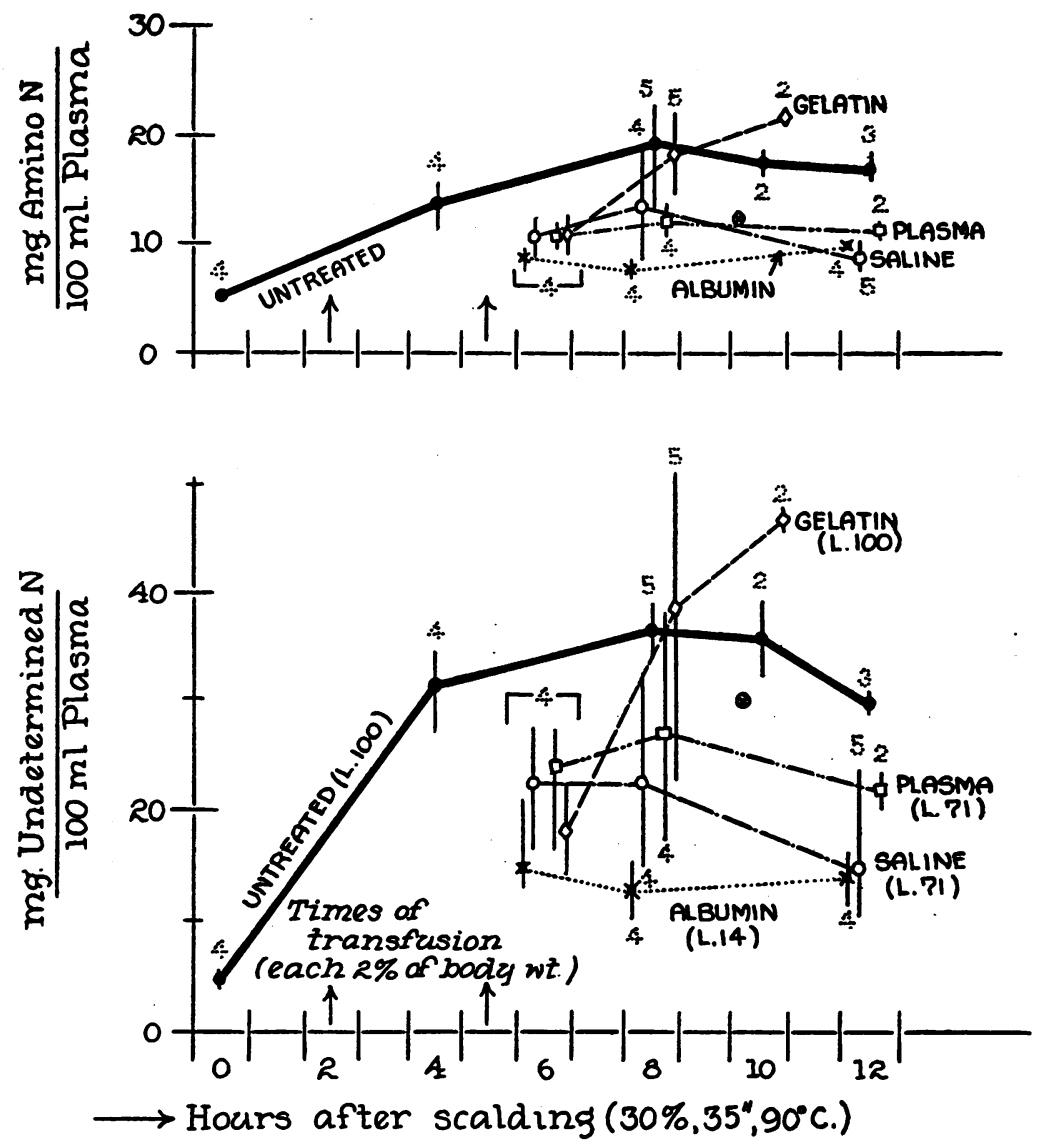

Fig. 2. Amino Nitrogen and Undetermined Nitrogen Levels in the Plasma of Scalded Rats Following Different Types of Fluid RePLACEMENT THERAPY

Scald : 30 per cent body surface, $90^{\circ} \mathrm{C}$., 35 seconds. The analyses were done upon plasma from individual rats.

Note that in the diagram the units of time as marked on the abscissa are represented by the distances between the pairs of vertical lines instead of by points. Within the vertical columns thus formed the values for each of the 5 experimental groups are plotted at arbitrary, but constant, positions with reference to the abscissa. This arrangement prevents the overlapping of the 5 plots. The points of the curves show the group means for each interval of time. The light vertical lines through these points indicate the difference between the highest and the lowest individual analysis while the numerals refer to the number of rats examined. The encircled daggers designate the analyses in an individual moribund rat following albumin treatment. This value has been omitted from the general plot of the albumin group.

A comparison of the plasma nitrogen values with the mortality rates (L) presented in Figures 2 and 3 shows that the response of the undetermined nitrogen levels brought out most strikingly the differences in efficacy of the various types of fluid replacement therapy. It is seen from Figure 2 that albumin infusion, which yielded the lowest mortality rate, was most effective in permanently reducing the undetermined nitrogen levels. This is contrasted to the transient effect of gelatin infusion which did not produce a single cure. Normal rat plasma and physiological saline solution 
had an intermediary position with reference to the reduction of the undetermined nitrogen levels and to the lowering of the mortality rates.

The amino nitrogen levels, which are also given in Figure 2, showed trends similar to those of the undetermined nitrogen levels. The differences between the treated and untreated groups were, however, less pronounced. Only following albumin treatment were the group means significantly below those of the controls during the entire experimental period. Plasma infusion resulted in statistically significant reductions at the 8- and 12hour post-burn interval while the reduction following saline treatment became significant not before 12 hours following the scalding. Gelatin infusion failed to produce significant reductions at any interval of time. The urea nitrogen levels (Figure 3 ) were not significantly different in the 5 experimental groups under comparison.

Inspection of the data presented in Table I reveals the following details regarding the undetermined nitrogen levels. Six hours after the burn, i.e., 1 hour after the final infusion, the levels in all treated groups were significantly lower than they had been 4 hours after the burn in the untreated controls. Albumin and gelatin appeared to be slightly more effective than physiological saline

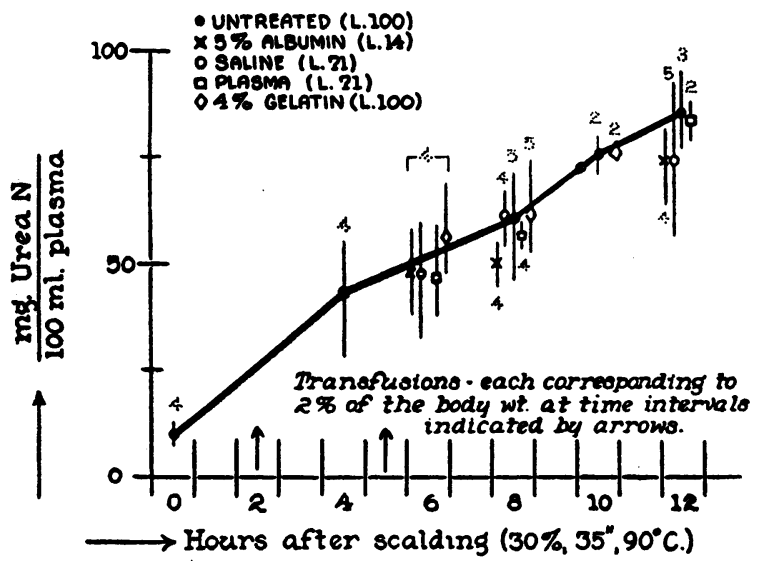

Fig. 3. Urea Nitrogen Levels in the Plasma of Scalded Rats Following Different Types of Fluid REPLACEMENT THERAPY

Experimental and diagrammatic arrangements and abbreviations are explaiped in the legend to Figure 2. Only in the untreated control series have the group means for each interval of time been connected by a curve. None of the group means in the treated series differed signifcantly from the corresponding control mean.
TABLE I

The effect of fluid therapy on the undetermined nitrogen levels

\begin{tabular}{|c|c|c|c|c|c|c|c|}
\hline \multirow{2}{*}{ Group } & \multirow{2}{*}{$\begin{array}{l}\text { Time } \\
\text { after } \\
\text { burn }\end{array}$} & \multirow{2}{*}{$\begin{array}{c}\text { No. } \\
\text { of } \\
\text { rats } \\
n\end{array}$} & \multicolumn{2}{|c|}{$\begin{array}{l}\text { Undetermined } \\
\text { nitrogen mean } \\
\text { values }\end{array}$} & \multicolumn{3}{|c|}{$\begin{array}{c}\text { Change of undetermined } \\
\text { nitrogen due to } \\
\text { therapy }\end{array}$} \\
\hline & & & $x$ & $S x^{*}$ & $\Delta \bar{x}$ & $S \Delta \overline{x t}$ & $P t$ \\
\hline $\begin{array}{l}\text { Untreated } \\
\text { Gelatin } \\
\text { Plasma } \\
\text { Saline } \\
\text { Albumin }\end{array}$ & $\begin{array}{c}\text { hrs. } \\
4 \\
6 \\
6 \\
6 \\
6\end{array}$ & $\begin{array}{l}4 \\
4 \\
4 \\
4 \\
4\end{array}$ & $\begin{array}{c}\text { mgm. } \\
\text { per cent } \\
31.9 \\
18.5 \\
23.7 \\
22.5 \\
14.9\end{array}$ & $\begin{array}{l} \pm 1.59 \\
\pm 1.90 \\
\pm 2.44 \\
\pm 2.34 \\
\pm 2.00\end{array}$ & $\begin{array}{l}-13.5 \\
-8.2 \\
-9.5 \\
-17.0\end{array}$ & $\begin{array}{l} \pm 2.50 \\
\pm 2.95 \\
\pm 2.86 \\
\pm 2.75\end{array}$ & $\begin{array}{l}<0.01 \\
<0.05 \\
<0.02 \\
<0.01\end{array}$ \\
\hline $\begin{array}{l}\text { Untreated } \\
\text { Gelatin } \\
\text { Plasma } \\
\text { Saline } \\
\text { Albumin }\end{array}$ & $\begin{array}{l}8 \\
8 \\
8 \\
8 \\
8\end{array}$ & $\begin{array}{l}5 \\
5 \\
4 \\
4 \\
4\end{array}$ & $\begin{array}{l}36.4 \\
38.2 \\
27.7 \\
22.9 \\
13.1\end{array}$ & $\begin{array}{l} \pm 0.91 \\
\pm 7.60 \\
\pm 5.10 \\
\pm 2.64 \\
\pm 1.28\end{array}$ & $\begin{array}{l}+1.8 \\
-8.7 \\
-13.5 \\
-23.3\end{array}$ & $\begin{array}{l} \pm 7.66 \\
\pm 5.19 \\
\pm 2.80 \\
\pm 1.28\end{array}$ & $\begin{array}{l}>0.08 \\
>0.10 \\
<0.01 \\
<0.01\end{array}$ \\
\hline $\begin{array}{l}\text { Untreated } \\
\text { Plasma } \\
\text { Saline } \\
\text { Albumin }\end{array}$ & $\begin{array}{l}12 \\
12 \\
12 \\
12\end{array}$ & $\begin{array}{l}3 \\
2 \\
5 \\
4\end{array}$ & $\begin{array}{l}30.0 \\
22.0 \\
15.2 \\
14.0\end{array}$ & $\begin{array}{l} \pm 0.55 \\
\pm 0.14 \\
\pm 2.49 \\
\pm 1.03\end{array}$ & $\begin{array}{l}-8.0 \\
-14.8 \\
-16.0\end{array}$ & $\begin{array}{l} \pm 0.57 \\
\pm 2.55 \\
\pm 1.17\end{array}$ & $\begin{array}{l}<0.01 \\
<0.01 \\
<0.01\end{array}$ \\
\hline
\end{tabular}

${ }^{2}$ where $S x_{n}$ and $S x_{t}$ designate the standard errors of the means of the untreated and treated groups, respectively.

$\ddagger P=$ probability of $\Delta x$ to have arisen by chance. The $P$ values are taken from Fisher's (7) table of $t$.

solution and plasma. During the following 2 hours, however, marked differences developed among the 4 groups of infused animals. While the group means for the albumin and saline series remained significantly below that of the untreated controls, the difference between gelatintreated and untreated animals disappeared and the difference between the plasma group and the controls became statistically insignificant. While the mean for the albumin group was significantly below that of any other treated group, the differences among the 3 other groups were not statistically significant due to the large range of variation of the individual values. The large scatter range in the saline, plasma and gelatin groups can be most readily seen from Figure 2 . Since burned rats in extremis always exhibited greatly increased undetermined nitrogen levels, heterogeneity of the group can be considered as an indication that in several -individuals the beneficial effect of the transfusion had already disappeared and that death was near, although the apparent conditions of most of the treated animals was fair to good at the 8-hour interval of time. During the following 4 hours, however, 70 per cent of the gelatin group, 36 per cent of the plasma group, 20 per 
cent of the saline group, and 10 per cent of the albumin group died.

It should be noted that, from the standpoint of alterations from the normal, none of the therapeutic measures can be designated as adequate for the treatment of this particularly severe burn; for, contrary to the 100 per cent successful saline therapy illustrated in Figure 1, all types of fluid therapy failed to reduce to normal the increased undetermined nitrogen levels within a period of 12 hours.

\section{Azotemia and hemoconcentration}

Figure 4 serves to demonstrate that gelatin, plasma, and albumin were about equally effective in relieving the hemoconcentration of burn shock and in maintaining the restored plasma volume.
Saline therapy resulted in a temporary hemodilution and hypoproteinemia which disappeared within 3 hours of the last infusion. This was followed spontaneously by a second period of hemodilution with constant plasma protein levels. It is obvious that the effects of these agents upon hemoconcentration do not throw light upon the reasons for their different therapeutic efficacy. Nor can hemodilution per se be considered as the essential mechanism in the reduction of the increased undetermined and amino nitrogen levels.

\section{The effect of fluid replacement therapy on water and nitrogen excretion}

Table II provides information on urinary nitrogen and water excretion and fluid intake of normal rats during 5 days of feeding and 1 day of

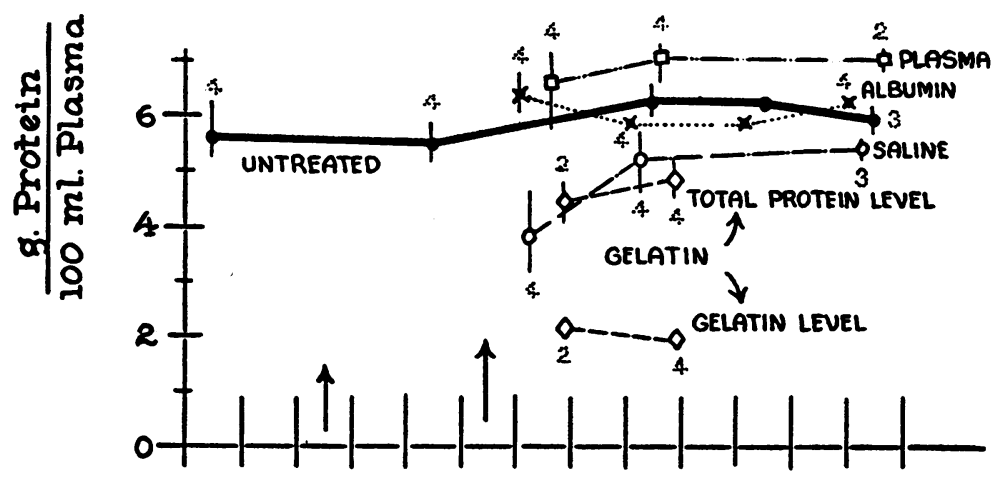

Change of Plasma Volume (Computed from Hematocrits)

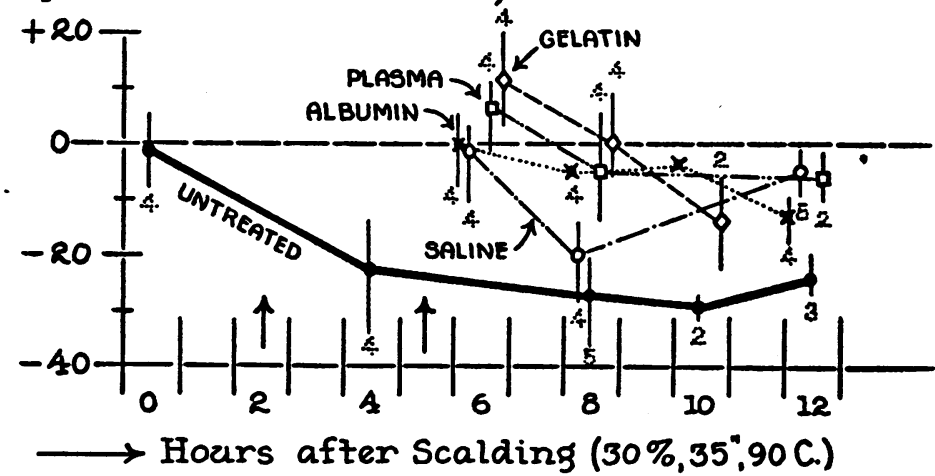

Fig. 4. Changes of Plasma Volume and Plasma Protein Levels in Scalded Rats following Different Types of Fluid Replacement THERAPY

Diagrammatic arrangement as in Figure 2. Hematocrit readings were done upon tail blood. If $I$ is the hematocrit value (expressed as percentage) before the scalding and $F$ the hematocrit reading at the time the animal was sacrificed, then the percentile change $(\Delta V)$ of the plasma volume is

$$
\Delta V=\frac{[(100-F)-(100-I)] 100}{100-I}=\left(\frac{I-F}{100-I}\right) 100 .
$$


TABLE II

Daily food and water intake, nitrogen excretion, and urine volume prior to the scald

\begin{tabular}{|c|c|c|c|c|c|c|c|c|}
\hline \multirow[b]{3}{*}{ Rat no. $\longrightarrow$} & \multicolumn{8}{|c|}{ Nutritional state } \\
\hline & \multicolumn{4}{|c|}{ Fed* } & \multicolumn{4}{|c|}{ Fast** } \\
\hline & 1 & 2 & 3 & 4 & 1 & 2 & 3 & 4 \\
\hline $\begin{array}{l}\text { a. Body weight-grams } \\
\text { b. Food intake-grams } \\
\text { c. Urea }+\mathrm{NH}_{3} \mathrm{~N}-m g m . \\
\text { (c/total } \mathrm{N} \text { ) } 100 \text {-per cent } \\
\text { d. Exogenous } \mathrm{N}=\mathrm{c} \text { fed-c fast -mgm. } \\
\text { (d/c fed) } 100 \text {-per cent } \\
\mathrm{d} / \mathrm{b}-m g m . \text { per gram } \\
\text { e. Undetermined } \mathrm{N}=\text { Total } \mathrm{N}-\mathrm{c}-m g m . \\
\text { (e fast/e fed) } 100 \text {-per cent } \\
\text { f. Water intake-ml. } \\
\text { g. Urine volume -ml. }\end{array}$ & $\begin{array}{r}181.0 \\
15.6 \\
214.0 \\
91.0 \\
113.0 \\
53.0 \\
7.3 \\
20.0 \\
17.4 \\
7.2\end{array}$ & $\begin{array}{r}196.0 \\
13.1 \\
236.0 \\
89.5 \\
117.0 \\
49.5 \\
9.0 \\
28.0 \\
22.5 \\
9.4\end{array}$ & $\begin{array}{r}190.5 \\
14.2 \\
243.0 \\
90.0 \\
128.0 \\
52.5 \\
9.1 \\
27.0 \\
\\
23.4 \\
7.0\end{array}$ & $\begin{array}{r}204.0 \\
13.8 \\
249.0 \\
90.0 \\
115.0 \\
46.5 \\
8.4 \\
27.0 \\
\\
28.8 \\
10.4\end{array}$ & $\begin{array}{r}20.0 \\
100.0 \\
1.0 \\
6.4\end{array}$ & $\begin{array}{c}180.0 \\
0 \\
119.0 \\
84.0\end{array}$ & $\begin{array}{r}174.0 \\
0 \\
115.0 \\
82.5\end{array}$ & $\begin{array}{c}186.0 \\
0 \\
134.0 \\
84.5\end{array}$ \\
\hline
\end{tabular}

* The data are averages for 5 experimental days, 2 before and 3 after the day of fast. The rats were scalded on the fourth day after the fast. Post-burn data are presented in Figure 5.

** Water was withheld for 12 hours in the daytime in order to simulate the post-burn conditions.

$\dagger$ This term should be considered as only a minimal estimate of the exogenous nitrogen because part of the nitrogen excreted during a single day of fast will still be of exogenous origin. Exposure of the rats to longer periods of starvation was not attempted as it would probably have altered their resistance to the scald.

$\ddagger$ In general, approximately $\frac{2}{3}$ of the urine was excreted during the night hours.

fast. Fasting reduced the output of urea + ammonia by approximately 50 per cent while the excretion of undetermined nitrogen and of water was not affected by the nutritional state of the animal. The urea + ammonia excretion during the period of feeding showed the smallest individual variations and the water intake and output the largest.

The experiments upon scalded rats listed in Table III concern the response of urinary excretion to saline therapy corresponding to 10 per cent of the animal's body weight. Data are presented on 2 successive 12-hour periods following the scalding and on 2 types of fatal burn in which the treatment leads to 100 per cent recovery of the animals. It is seen from Table III that in untreated rats, water excretion and, especially urea elimination, virtually ceased. Following the infusion of physiological saline solution the urinary volumes during the first 12 post-burn hours were of a similar order of magnitude as in normal rats during a 12 -hour period in the daytime. Abnormal chemical findings in the urines consisted of hemoglobin and low ratios of urea nitrogen to total non-protein nitrogen. The ratio of ammonia nitrogen to non-protein nitrogen, which is not recorded in the table, remained essentially normal (about 6 per cent). During the sec- ond 12 hours after the burn, when the animals had access to water, large volumes of urine with a normal nitrogen distribution were excreted. As in fasting normal animals, considerable individual variations were encountered with reference to the quantities of water and nitrogen excreted during the 212 -hour periods. On the average, the amount of urea + ammonia nitrogen $(142 \pm 8.2 \mathrm{mgm}$.$) excreted during the first 24$ post-burn hours by the group of 6 rats reported in Table II was slightly above the corresponding mean $(117 \pm 6.5 \mathrm{mgm}$.) for fasted normal rats. The mean value for the undetermined nitrogen $(30.1 \pm 3.1 \mathrm{mgm}$.) was also higher than that $(23 \pm 1.08 \mathrm{mgm}$.) for the unburned controls, but this difference was not statistically significant.

Table IV shows the effects of 2 inadequate types of fluid therapy upon the urinary excretion of rats subjected to a 30 per cent surface-35-second scald. As mentioned before, in this type of 100 per cent lethal burn saline infusion corresponding to 4 per cent of the animal's body weight yielded only 29 per cent survival while the infusion of gelatin had no curative value. The saline-treated animals of the experimental series presented in Table IV were in good clinical condition when sacrificed 12 hours after the burn, whereas the gelatin-treated rats were moribund at the time of blood collec- 
TABLE III

Urine volume, nitrogen excretion, and plasma nitrogen levels in saline-treated scalded rats

\begin{tabular}{|c|c|c|c|c|c|c|c|c|c|}
\hline \multirow{3}{*}{ Animals } & \multirow{3}{*}{$\begin{array}{c}\text { Interval } \\
\text { after } \\
\text { burn }\end{array}$} & \multirow{3}{*}{$\begin{array}{c}\text { Fluid } \\
\text { intake }\end{array}$} & \multirow{3}{*}{$\begin{array}{c}\text { Urine } \\
\text { volume }\end{array}$} & \multicolumn{6}{|c|}{ Non-protein nitrogen } \\
\hline & & & & \multicolumn{3}{|c|}{ In urine volume excreted } & \multicolumn{3}{|c|}{ Per $100 \mathrm{ml}$. of plasma* } \\
\hline & & & & $\begin{aligned} \text { Urea } \\
+\mathrm{NH}_{2} \mathrm{~N}\end{aligned}$ & $\begin{array}{l}\text { Undeter- } \\
\text { mined } N^{* *}\end{array}$ & $\frac{\text { Urea }+\mathrm{NH}_{2} \mathrm{~N}}{\text { Total NPN }}$ & Urea $\mathbf{N}$ & $\mathrm{NH}_{2} \mathrm{~N}$ & $\begin{array}{l}\text { Undeter- } \\
\text { mined } N^{* *}\end{array}$ \\
\hline & hrs. & $m l$. & $m l$. & mgm. & mgm. & per cent & $\underset{\text { per cent }}{\operatorname{mgm} .}$ & $\underset{\text { per cent }}{\operatorname{mgm} .}$ & $\underset{\text { per cent }}{\operatorname{mgm}}$ \\
\hline \multicolumn{10}{|c|}{ Scald: 45 per cent surface, $90^{\circ} \mathrm{C} ., 15$ seconds } \\
\hline $\begin{array}{r}\text { Mean-4 Rats } \dagger \\
\text { Rat number } 1 \\
\text { Rat number } 2 \\
\text { Rat number } 2\end{array}$ & $\begin{array}{c}12 \\
12 \\
12 \\
12-24\end{array}$ & $\begin{array}{l}0 \\
20.4 \ddagger \\
19.9 \ddagger \\
27.0\end{array}$ & $\begin{array}{l}0.1 \\
2.4 \\
1.5 \\
7.0\end{array}$ & $\begin{array}{l}21.4 \\
16.3 \\
94.7\end{array}$ & $\begin{array}{r}17.5 \\
18.1 \\
8.9\end{array}$ & $\begin{array}{l}55.0 \\
47.5 \\
91.5\end{array}$ & $\begin{array}{l}54.3 \\
32.6\end{array}$ & $\begin{array}{r}11.1 \\
7.8\end{array}$ & $\begin{array}{l}3.8 \\
3.3\end{array}$ \\
\hline Mean-6 Rats & $\begin{array}{c}12 \\
12-24\end{array}$ & $\begin{array}{l}19.8 \\
35.0\end{array}$ & $\begin{array}{r}2.0 \\
18.0\end{array}$ & $\begin{array}{r}19.3 \\
121.9\end{array}$ & $\begin{array}{l}15.2 \\
15.4\end{array}$ & $\begin{array}{l}55.0 \\
88.5\end{array}$ & & & \\
\hline
\end{tabular}

Scald: 35 per cent surface, $90^{\circ}$ C., 25 seconds

\begin{tabular}{r|c|c|c|c|c|c|c|c|c}
\hline Mean-4 Rats† & 12 & 0 & 0.2 & & & 30.59 & $89.2 \S$ & $25.4 \S$ & $25.6 \S$ \\
Rat number 3 & 12 & $19.0 \ddagger$ & 3.6 & 71.6 & 29.1 & 59.5 & 54.3 & 9.1 & 5.5 \\
Rat number 4 & 12 & $22.0 \ddagger$ & 4.3 & 43.4 & 21.0 & 49.5 & 53.8 & 9.1 & 6.5 \\
Rat number 5 & 12 & $19.0 \ddagger$ & 2.5 & 62.0 & 16.4 & 73.5 & & \\
Rat number 5 & $12-24$ & 33.0 & 31.0 & 99.1 & 3.8 & 96.0 & 13.2 & 6.2 & 1.4 \\
\hline
\end{tabular}

* At the end of the period given in column 3 .

** Undetermined nitrogen in urine = non-protein nitrogen-(urea nitrogen + ammonia nitrogen). Undetermined nitrogen in plasma $=$ non-protein nitrogen-(urea nitrogen + amino nitrogen).

t Rats kept in single metabolic cage.

$\ddagger$ Volume of intravenous saline infusion corresponding to 10 per cent of the animal's body weight. Forty per cent of the total volume were given 2 hours post-burn, the remaining 60 per cent in equal doses 5 and 8 hours post-burn.

$\$$ Three rats died 8 to 9 hours after the scald. The survivor was used for plasma analysis.

Nineteen per cent urea nitrogen and 11 per cent ammonia nitrogen. The non-protein nitrogen concentration was 1.2 grams per $100 \mathrm{ml}$. of urine.

tion, between 7.5 and 10.5 hours after the burn. Yet the urine volumes of the gelatin-treated rats were within the range previously obtained with corresponding periods of time in scalded rats which received an adequate saline therapy. There was only one statistically significant difference in the urinary excretion following gelatin treatment. The concentration of urea + ammonia nitrogen averaged $0.41 \pm 0.05$ gram per $100 \mathrm{ml}$. of urine as contrasted to an average concentration of $0.96 \pm$ $0.10 \mathrm{gram}$ in the urine of 11 saline-treated rats during the first 12 hours following the scalding. This suggests the possibility that the concentration ability of the kidney was impaired in the gelatintreated rats.

Figure 5 serves to illustrate the nitrogen èxcretion of saline-treated rats over longer postburn periods. The same type of scald as in the last experimental series was used, but the in- fusion was increased to 10 per cent of the animal's body weight with the result that, on the average, 86 per cent of the rats survived. In the graph all quantities are represented as percentages of the corresponding pre-burn values for the fed state which are recorded in Table II. Note that the exogenous urea + ammonia nitrogen excretion is a measure of the food intake of the animal during the post-burn period:

$$
\mathrm{d} \text { post-burn }=\mathrm{b} \text { post-burn } \times(\mathrm{d} / \mathrm{b}) \text { pre-burn }
$$

where, as in Table II, $\mathrm{d}$ and $\mathrm{b}$ designate "exogenous" nitrogen and food intake, respectively. The quantity recorded in Figure 5 is the ratio:

$$
\text { (d post-burn/c fed pre-burn) } \times 100
$$

c being the total daily excretion of urea + ammonia nitrogen. Prior to the burning, the ratio $(d / c$ fed $) \times 100$ approximated 50 per cent. Hence 
TABLE IV

Urinary water and nitrogen excretion in scalded rats infused with saline or gelatin Scald: 30 per cent body surface, $90^{\circ} \mathrm{C} ., 35$ seconds

\begin{tabular}{|c|c|c|c|c|c|c|c|c|}
\hline \multirow{3}{*}{ No. } & \multirow{3}{*}{$\begin{array}{c}\text { Interval } \\
\text { after burn }\end{array}$} & \multirow{3}{*}{$\begin{array}{c}\text { Urine } \\
\text { volume }\end{array}$} & \multicolumn{6}{|c|}{ Non-protein nitrogen } \\
\hline & & & \multicolumn{3}{|c|}{ Amount excreted in urine volume } & \multicolumn{3}{|c|}{ Plasma concentration } \\
\hline & & & $\begin{array}{l}\text { Undeter- } \\
\text { mined N }\end{array}$ & Urea $+\mathrm{NH}_{3} \mathbf{N}$ & $\frac{\text { Urea }+\mathrm{NH}_{3} \mathrm{~N}}{\text { Total NPN }}$ & $\begin{array}{l}\text { Undeter- } \\
\text { mined N }\end{array}$ & $\mathrm{NH}_{2} \mathrm{~N}$ & Urea $\mathbf{N}$ \\
\hline & hrs. & $m l$. & $m g m$. & mgm. & per cent & \multicolumn{3}{|c|}{ mgm. per cent } \\
\hline
\end{tabular}

Knox P-20 gelatin solution-4 per cent*

\begin{tabular}{|c|c|c|c|c|c|c|c|c|}
\hline $\begin{array}{l}1 \\
2 \\
3 \\
4\end{array}$ & $\begin{array}{r}7.5 \\
9.1 \\
9.2 \\
10.6\end{array}$ & $\begin{array}{l}1.6 \\
1.5 \\
1.2 \\
3.1\end{array}$ & $\begin{array}{r}8.5 \\
9.5 \\
8.1 \\
22.5\end{array}$ & $\begin{array}{r}5.7 \\
4.4 \\
5.8 \\
15.2\end{array}$ & $\begin{array}{l}40 \\
31 \\
42 \\
41\end{array}$ & $\begin{array}{l}50.9 \\
48.3 \\
\\
45.8\end{array}$ & $\begin{array}{l}24.9 \\
22.0 \\
\\
20.8\end{array}$ & $\begin{array}{l}74.3 \\
76.1 \\
75.9\end{array}$ \\
\hline \multicolumn{9}{|c|}{ Physiological saline solution* } \\
\hline $\begin{array}{l}5 \\
6\end{array}$ & $\begin{array}{l}12.0 \\
12.0\end{array}$ & $\begin{array}{l}2.9 \\
3.5\end{array}$ & $\begin{array}{l}24.8 \\
26.9\end{array}$ & $\begin{array}{l}23.6 \\
39.2\end{array}$ & $\begin{array}{l}49 \\
59\end{array}$ & $\begin{array}{l}24.2 \\
11.9\end{array}$ & $\begin{array}{l}9.8 \\
8.0\end{array}$ & $\begin{array}{l}93.0 \\
80.1\end{array}$ \\
\hline
\end{tabular}

* Infused intravenously at 2 and 5 hours after the scalding. The volume of each infusion (approximately $4.0 \mathrm{ml}$.) corresponded to 2 per cent of the body weights which ranged from 201 to 215 grams. The total volume (8.0 mi.) infused was approximately equal to the normal plasma volume of the rat.

in Figure 5, the 50 per cent level of the exogenous urea + ammonia nitrogen designates normal food intake.

Rat No. 4 of Table II died 10 hours after the burn in spite of the saline treatment. No urine was excreted, and the plasma nitrogen levels were as high as in the untreated controls. In rats Nos. 2 and 3 the excretion of urea + ammonia nitrogen showed the usual initial drop to the pre-burn fasting level. On the second post-burn day the excretion reached the pre-burn range for fed animals even though food consumption was still minimal. With the resumption of normal food intake ( 50 per cent level of "exogenous" nitrogen in Figure 5) on the fifth post-burn day, the urea + ammonia nitrogen excretion increased to about 20 per cent above the pre-burn average. It returned to normal the tenth day after the scalding. Rat No. 1 excreted during the first 24 post-burn hours 60 per cent less urea + ammonia nitrogen than during the pre-burn day of fast although the urine volume $(13.0 \mathrm{ml}$.) was as high as in rat No. $3\left(11.5 \mathrm{ml}\right.$.). ${ }^{5}$ The nitrogen excretion did

5 During the entire post-burn period the average daily urine output of the rats remained 2 to 3 times as high and the average fluid intake double as high as before the not reach the pre-burn level for fed animals before the third day. Food intake remained minimal, and the animal died on the fifth post-burn day. ${ }^{6}$

In the rats Nos. 1 to 3 the daily excretion of undetermined nitrogen averaged 37.0, 33.0, and $42.0 \mathrm{mgm}$., respectively, during the first 4 postburn days, i.e., it was 83,45 , and 74 per cent above the fasting level and 83,19 , and 54 per cent above the average level in the fed state. The absolute quantities of undetermined nitrogen excreted were small in comparison with the total amount of urinary non-protein nitrogen. This is in keeping with the statement of Clark, Peters and Rossiter

scalding. In contrast to the fairly constant rates of nitrogen excretion the daily fluctuations of the fluid exchange were extremely large. This phenomenon has to be re-examined since the possibility could not be excluded with certainty that the rats, whose movements were somewhat impaired owing to scar contractions, spilled drinking water into the collecting funnels.

- Because of the sudden death of this animal no blood for plasma analysis was secured. In rat No 2 which was sacrificed at the height of the urinary nitrogen excretion, as well as in rat No. 3 which was analyzed after the return of the nitrogen excretion to the pre-burn range, the non-protein nitrogen levels of the plasma were essentially normal. 
Post-burn Values
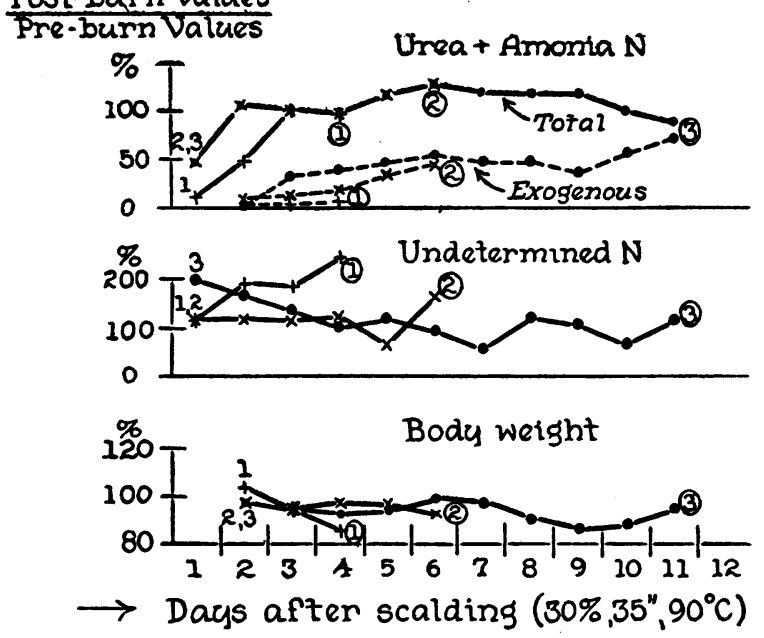

Fig. 5. DaIly Nitrogen Excretion and Weight Changes in Rats Recovering from Burn as a Result of Saline Therapy

Scald: 30 per cent body surface, $90^{\circ}$ C., 35 seconds. The volume of saline infused corresponded to 10 per cent of the animal's body weight. Infusion intervals as in Table III and Figure 1. In the graph all quantities are represented as percentages of the corresponding preburn values for the fed state (see Table II). Each curve shows the serial number of the rat to which it refers. Encircled numbers designate the last analysis prior to death or sacrifice of the animal.

(8) that thermal injury in the rat fails to produce the large excretion of undetermined nitrogen which has been reported $(9,10)$ to occur frequently in the burned human patients. It seems possible, however, that the time-course of the excretion may have some prognostic significance as rat No. 3, which recovered most rapidly from the scalding, showed the greatest initial rate of elimination of this nitrogen fraction.

\section{COMMENT}

It has been previously pointed out by us (1) that the accumulation of undetermined and amino nitrogen in the plasma of rats following scalding is probably the consequence of the thermal destruction of cells as well as of the post-burn shock. The latter leads to tissue hypoxia, increased nitrogen catabolism in peripheral tissues, decreased amino acid oxidation in the liver, and cessation of urinary excretion. It should be expected that the curative efficacy of a given type of fluid replacement therapy would be attested by the re- lief of any one of the 3 criteria of burn shock here examined: the anuria, the hemoconcentration, or the azotemia. While curatively effective types of fluid therapy always initiated the flow of urine and relieved hemoconcentration, curatively ineffective agents, such as gelatin infusion, were not inferior in this regard. They were, however, clearly distinguished from the effective types by the fact that they produced, in all or many animals, only a temporary reduction of the increased plasma levels of the undetermined and amino nitrogen. It seems possible that the renewed rise of the levels of these nitrogen fractions was the manifestation of a returning tissue anoxia, caused by a diminution of the actively circulating rather than of the total blood volume. Recent studies of Prinzmetal, Bergman, and Kruger (11) support the view that the shock following burns is characterized by a pronounced diminution of the circulating blood volume due to an atony of visceral blood capillaries.

\section{SUMMARY}

The effect of various types of fluid replacement therapy on the partition of the non-protein nitrogen of plasma and on the urinary water and nitrogen excretion was studied in rats subjected to standardized scalds of known lethality. The agents under comparison were physiological saline solution, gelatin solution, human albumin solution, and rat plasma. The following results have been obtained:

1. The degree of permanent reduction of the increased amino nitrogen and, especially, of the undetermined nitrogen levels of plasma provides a useful criterion of the efficacy of the treatment, whereas the reduction of the urea nitrogen is too slow and too irregular to be of use for this purpose.

2. The rates of urinary water and nitrogen excretion do not furnish a reliable index of curative efficacy. Complete failure of promoting the flow of urine proves, however, inefficiency of the treatment.

3. The effectiveness of fluid replacement therapy in permanently reducing the elevated undetermined nitrogen levels is not clearly related to the relief of hemoconcentration. It is suggested that a renewed rise of the undetermined plasma ni- 
trogen levels in spite of nearly normal hematocrit values is an indication of a returning tissue anoxia due to a diminution of the actively circulating rather than of the total blood volume.

\section{BIBLIOGRAPHY}

1. Rosenthal, Otto, and McCarthy, M. D., Post-burn azotemia, its characteristics and relationship to the severity of thermal injury. Am. J. Physiol., 1947, $148,365$.

2. McCarthy, M. D., A standardized back burn procedure for the white rat suitable for the study of the effects of therapeutic and toxic agents on long-term survival.. J. Lab. \& Clin. Med., 1945, 30, 1027.

3. Sobel, A. E., Mayer, A. M., and Gottfried, S. P., A convenient titrimetric ultramicromethod for the estimation of urea and Kjeldahl nitrogen. J. Biol. Chem., 1944, 156, 355.

4. Croft, P. B., and Peters, R. A., Nitrogen loss after thermal burns; effects of adding protein and methionine to the diet of rats. Lancet, 1945, 1, 266.

5. Nelson, V. E., and McCay, C. M., Metabolism and vitamin A. J. Metab. Research, 1925, 7, 199.

6. Rhoads, J. E., McCarthy, M. D., and Parkins, W. M., Personal communication.

7. Fisher, R. A., Statistical Methods for Research Workers. Oliver and Boyd, London, 1938.

8. Clark, E. J., Peters, R. A., and Rossiter, R. J., Nitrogen metabolism after burning. Quart. J. Exper. Physiol., 1945, 33, 113.

9. Taylor, F. H. L., Levenson ,S. M., Davidson, C. S., and Adams, M. A., Abnormal nitrogen metabolism in patients with thermal burns. New England J. Med., 1943, 229, 855.

10. Walker, J., Jr., A study of the azotemia observed after severe burns. Surgery, 1946, 19, 825.

11. Prinzmetal, M., Bergman, H. C., and Kruger, H. E., Demonstration of a toxic factor in blood of rats shocked by burn. J. Clin. Invest., 1946, 25, 781. 